\title{
PRZYGRANICZNE TARGOWISKA JAKO KURCZACA SIE FORMA ORGANIZACJI PRZESTRZENNEJ HANDLU DETALICZNEGO W CIESZYNIE
}

\author{
Dr Katarzyna Kulczyńska - Uniwersytet im. Adama Mickiewicza w Poznaniu \\ Wydział Geografii Społeczno-Ekonomicznej i Gospodarki Przestrzennej \\ Zakład Geografii Społecznej \\ ul. Bogumiła Krygowskiego 10, 61-680 Poznań \\ e-mail: katakul@amu.edu.pl
}

ZARYS TREŚCI: W artykule przedstawiono zmiany, jakie zaszły na przygranicznych targowiskach w Cieszynie, ze szczególnym uwzględnieniem bazarów przy al. Łyska i ul. Katowickiej. Od końca lat 90. XX wieku ulegają one stopniowemu kurczeniu się zarówno pod względem liczby konsumentów, jak i liczby stanowisk handlowych. Mimo to nadal stanowią jedną z ważniejszych form działalności handlowych prowadzonych w Cieszynie.

SŁOWA KLUCZOWE: handel targowiskowy, struktura rodzajowa stanowisk handlowych, natężenie ruchu konsumentów, Cieszyn.

\section{FRONTIER MARKETPLACES AS A SHRINKING FORM OF THE SPATIAL ORGANISATION OF RETAIL TRADE IN CIESZYN}

ABSTRACT: The paper presents changes that have taken place at the cross-border marketplaces in Cieszyn, with a particular emphasis on two of them, located in Łyska and Katowicka Streets. Since the end of the 1990s, they have been gradually shrinking both in terms of the number of consumers and the number of stalls. Nevertheless, they still constitute one of the most important forms of commercial activity in Cieszyn.

KEYWORDS: marketplace trade, branch structure of stalls, intensity of consumer traffic, Cieszyn. 


\subsection{Wprowadzenie}

Handel targowiskowy to jedna z najstarszych form handlu detalicznego, która do dziś jest ważnym miejscem realizacji zakupów (Zuzańska-Żyśko 2010; Wojdacki 2011, 2016; Zuzańska-Żyśko, Sitek 2011; Malinowska 2016). W sporządzonej przez Ministerstwo Rolnictwa i Rozwoju Wsi Metodologii badań rynku targowiskowego... (2002: 5), targowisko definiuje się jako „wyodrębniony teren, plac (niekiedy ogrodzony), na którym odbywa się lokalna sprzedaż produktów rolnych (zwierzęcych i roślinnych) między producentami rolnymi (rolnikami) oraz jednostkami handlowymi lub między rolnikami a ludnością nierolniczą w wyznaczone dni tygodnia". Zaprezentowana definicja ogranicza się wyłącznie do targowisk sprzedających płody rolne, tymczasem szerszą i bardziej ogólną definicję podaje GUS. Przez targowisko rozumie się ,wyodrębnione tereny lub budowle (plac, ulica, hala targowa) ze stałymi, względnie sezonowymi punktami sprzedaży drobnodetalicznej lub urządzeniami przeznaczonymi do prowadzenia handlu, codziennie lub w wyznaczone dni tygodnia" (Rynek Wewnętrzny... 2015: 14).

Według A. Werwickiego (2001) w Polsce pierwsze geograficzne studia dotyczące handlu targowiskowego prowadzono już w latach 30 . XX wieku, które kontynuowano po II wojnie światowej. Niemniej badanie bazarów zyskało na znaczeniu dopiero od lat 90. XX wieku, kiedy to nastąpił prawdziwy boom targowiskowy, szczególnie w obszarach przygranicznych, będący konsekwencją otwarcia szczelnych dotąd granic państwowych (Kłosowski, Runge 1999, 2002; Powęska 2002, 2003, 2007, 2016; Klima, Zajączkowski 2008; Dołzbłasz 2013, 2015). Kolejnymi, komplementarnymi czynnikami żywiołowego rozwoju handlu transgranicznego, w tym przede wszystkim bazarowego, były różnice cen i dochodów po obu stronach granicy, jak również niedorozwój infrastruktury handlowej, będącej wynikiem poprzedniego systemu gospodarczego, prywatyzacja handlu, wzrost przedsiębiorczości, a przede wszystkim transformacja gospodarcza, która zapoczątkowała wszystkie te zmiany (Powęska 2002; Kropiwnicki 2003; Zuba M., Zuba J. 2018). Handel targowiskowy był jednym z najbardziej widocznych efektów przeobrażeń społeczno-gospodarczych w obszarach przygranicznych, które zawsze były położone peryferyjnie (Kowalczyk, Nawrocki 1999). Zwiększenie przepuszczalności granic państwowych spowodowało wzrost przemieszczeń przez granicę, a wraz z nim nastąpił rozwój handlu targowiskowego, głównie w wyniku dużego zainteresowania obcokrajowców zakupami po stronie polskiej. A. Werwicki (2001) rozumie handel graniczny jako nieformalną międzynarodową wymianę towarową, dokonywaną najczęściej na bazarach nastawionych na obsługę dużej liczby kupujących. Natomiast B. Nitschke (2010: 39) pod pojęciem handlu przygranicznego rozumie zakupy cudzoziemców dokonywane w bezpośrednim sąsiedztwie granicy na targowiskach znajdujących się w przygranicznych miejscowościach. 
Celem artykułu jest przedstawienie tendencji zmian przygranicznego handlu targowiskowego w Cieszynie, który od końca lat 90. ubiegłego wieku ulega stopniowemu kurczeniu się. Główne problemy badawcze skonstruowano w postaci pytań poznawczych, które przedstawiają się następująco: (1) Jakie cechy organizacyjno-administracyjne i funkcjonalne posiadają cieszyńskie bazary? (2) Jaka jest struktura rodzajowa stoisk handlowych na bazarach? (3) Jakie jest natężenie ruchu konsumentów na cieszyńskich bazarach w dni targowe? (4) Jak oceniają targowiska przygraniczne jego użytkownicy? Zakres prowadzonych badań wymagał wykorzystania danych statystycznych GUS (wtórne źródło informacji), ale przede wszystkim materiałów o charakterze pierwotnym o różnym stopniu szczegółowości. Prowadzone bezpośrednio w terenie badania polegały na: (a) pomiarze natężenia ruchu konsumentów na bazarach w dni targowe, (b) inwentaryzacji bazarowych placówek handlowych, (c) badaniu ankietowym użytkowników targowiska, którą przeprowadzono wśród 119 respondentów odwiedzających cieszyńskie bazary. Ankieta składała się z ośmiu pytań dotyczących m.in. stosunku użytkowników do cieszyńskich bazarów, identyfikacji problemów związanych $\mathrm{z}$ ich funkcjonowaniem, form ewentualnego utrzymania targowisk oraz zakupów tam dokonywanych. Zakres czasowy prowadzonych analiz odnosi się do okresu po 1989 roku ze szczególnym uwzględnieniem roku 2014, kiedy to przeprowadzono badania terenowe.

\subsection{Cechy organizacyjno-administracyjne i funkcjonalne cieszyńskich bazarów}

Zdaniem K. Kulczyńskiej i R. Matykowskiego (2008) w strukturze przestrzenno-handlowej miasta Cieszyn można wyróżnić trzy charakterystyczne podsystemy ukierunkowane na konsumenta. Pierwszy z nich to tradycyjny handel drobnodetaliczny, który bez zakłóceń funkcjonował w latach 90. XX wieku. Następnie obok stałych placówek sprzedaży detalicznej, pojawiły się już na początku lat 90. XX wieku targowiska - drugi podsystem, szczególnie popularny w miastach granicznych (por. Matykowski, Schaefer 1996; Kulczyńska 2008; Kulczyńska $i$ in. 2009). Ta tradycyjna struktura handlu uległa istotnym zmianom na przełomie XX i XXI wieku kiedy to w przestrzeni handlowej miasta pojawiły się supermarkety - trzeci podsystem, modernizujący system handlowy Cieszyna. Pojawienie się w przestrzeni miasta wielkopowierzchniowych placówek handlowych doprowadziło z czasem do zmniejszenia liczby placówek handlu drobnodetalicznego (np. warzywniaków), ale także stoisk na targowiskach, które nie podołały konkurencji z supermarketami. Obecnie handel targowiskowy stanowi uzupełnienie innych form handlu detalicznego (Hamulczuk 2016; Wojdacki 2016; Sojkin, Michalak 2018), a nie dominuje, jak to miało miejsce w ostatniej dekadzie XX wieku. Stopniowe przejmowanie konsumentów z bazarów przez placówki handlowe 
i coraz liczniejsze supermarkety, sklepy dyskontowe spowodowało, że rozmiary głównych targowisk się zmniejszyły, inne zaś zupełnie zniknęły z przestrzeni miasta. Jak pisze I.T. Miecik (2016: 30) ,Niedaleko - bazar, miesiąc w miesiąc sto tysięcy klientów. Ale to kiedyś. Teraz ludzie jeżdżą do hipermarketów, którymi otorbiło się miasto".

Głównym czynnikiem wyznaczającym możliwości funkcjonalne handlu targowiskowego jest struktura wielkościowa i jakościowa targowisk. Bazując na danych statystycznych pobranych z BDL GUS przeprowadzono analizę zmian liczby i powierzchni targowisk oraz stałych punktów sprzedaży drobnodetalicznej ogółem w latach 1995-2018. Generalnie liczba targowisk w Cieszynie w badanym okresie zmniejszyła się z 9 do 6 , czyli o $1 \frac{1}{3}$. Jeszcze w latach 90 . zakończyły działalność bazary przy ul. 3 Maja i w Amfiteatrze, a na początku XXI wieku pojawiło się na krótko (2-3 lata) targowisko „Komercjal” przy ul. Rzeźniczej. Spadkowi liczby targowisk w badanym okresie towarzyszył spadek powierzchni targowisk ogółem o 10,1 tys. $\mathrm{m}^{2}$ (około $1 / 3,2018$ r. $-24,9$ tys. $\mathrm{m}^{2}$ ) oraz liczby stałych punktów sprzedaży drobnodetalicznej ogółem z 2600 do 770, a więc aż o $2 / 3$. W przypadku wszystkich badanych cech, po okresowych spadkach obserwowano niewielkie wzrosty, ale nigdy wartości te nie były wyższe od tych z początku lat 90 .

Według Głównego Urzędu Statystycznego w Cieszynie w 2018 roku funkcjonowało sześć targowisk stałych, w tym cztery targowiska miejskie, tj.: (a) targowisko przemysłowe przy ul. Katowickiej, (b) targowisko rolno-spożywcze przy ul. Stawowej, (c) Miejskie Hale Targowe przy ul. Stawowej 6, (d) miejsca do handlu artykułami rolno-spożywczymi przy ul. Stary Targ. Obok targowisk miejskich, w przestrzeni miasta funkcjonowały również targowiska prywatne przy ul. Stawowej, które przylegały do targowiska miejskiego przy ul. Katowickiej oraz bazar przy al. Łyska 7 .

Administracją targowisk miejskich zajmuje się Dział Targowisk Miejskich, będący komórką organizacyjną Miejskiego Zarządu Dróg, a ten z kolei jest jednostką organizacyjną Urzędu Miejskiego w Cieszynie utworzoną 1 lipca 2000 r. Pracownicy Działu Targowisk Miejskich są uprawnieni do pobierania opłat targowych, których wysokość określają Zarządzenia Burmistrza Miasta Cieszyna w sprawie opłat rezerwacyjnych na targowiskach miejskich w Cieszynie. Wielkość i zmiany wysokości dochodu własnego gminy pochodzącego z opłaty targowiskowej były zmienne w czasie. W analizie pominięto lata 2008-2011, gdyż dane statystyczne dla tego okresu okazały się mało wiarygodne (ryc. 1). Bazując na danych GUS zauważa się, że w latach 90 . ubiegłego wieku były one najwyższe, a maksymalna kwota jaka wpłynęła do budżetu miasta wynosiła $3,4 \mathrm{mln}$ zł (1997 r.). W 2018 roku wpływy z opłaty targowiskowej były najniższe i wynosiły już tylko 0,4 mln zł. Zatem różnica między najwyższymi (1997 r.) i najniższymi (2018 r.) dochodami wynosiła 3,0 mln zł. Spadkowi wpływów z opłaty targowi- 


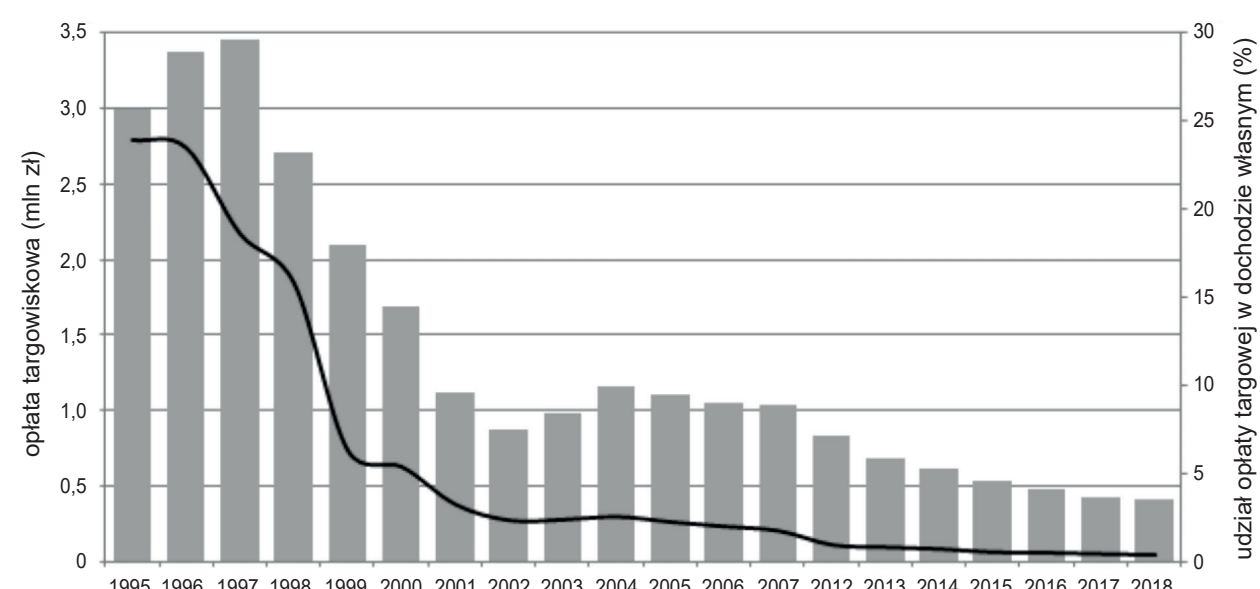

wpływy z opłaty targowej _u udział opłaty targowej w dochodach własnych

Ryc. 1. Wpływy z opłaty targowiskowej do budżetu miasta Cieszyn w latach 1995-2018 Źródło: oprac. własne na podstawie BDL GUS.

skowej do budżetu miasta towarzyszył spadek udziału tejże opłaty w dochodach własnych miasta. W 1995 roku wynosił on aż 24\%, natomiast od 1999 roku zaledwie kilka procent, a w latach 2013-2018 mniej niż 1\%. Wydaje się, że zasadniczy wpływ na zmniejszenie udziału opłaty targowej miał 8-krotny wzrost dochodów własnych z 12,5 mln zł w 1995 roku do 100,4 mln zł w 2018 roku, a także zmniejszenie liczby stoisk na targowiskach prawie o $2 / 3$ (z 2600 do 770 stałych punktów sprzedaży drobnodetalicznej), co bezpośrednio przełożyło się na zmniejszenie wpływów z opłaty targowej.

Dalszej, bardziej szczegółowej analizie poddano dwa główne targowiska w Cieszynie, jedno położone przy ul. Katowickiej (targowisko miejskie, tzw. duże targowisko), a drugie przy al. Łyska (targowisko prywatne, tzw. małe targowisko). Ich charakterystykę prezentuje tab. 1. Bazar przy ul. Katowickiej położony jest w północno-wschodniej części miasta, w niedalekiej odległości od dworca PKP $(0,4 \mathrm{~km})$, „Galerii Stela” $(0,45 \mathrm{~km})$ czy supermarketu „Kaufland” $(0,1 \mathrm{~km})$. Powstał on na początku lat 90. XX w., a jego głównymi klientami są Czesi (Kulczyńska, Matykowski 2008). Bazar wyposażony jest w 337 stanowisk handlowych skupionych na obszarze o powierzchni ok. 1,7 ha. Warto również wspomnieć, że wielu handlowców zajmuje więcej niż jedno stanowisko (przede wszystkim sprzedawcy odzieży), stąd liczba handlujących na bazarze jest mniejsza niż liczba użytkowanych stoisk. Jak podaje Miejski Zarząd Dróg w Cieszynie ${ }^{1}$, bazar funkcjonuje w środy i soboty w godzinach od 4:00 do 12:30.

${ }^{1}$ https://bip.um.cieszyn.pl/artykuly/1458/miejsce-handlowe-na-terenie-targowisk (dostęp: 23.03.2020). 
Tabela 1. Charakterystyka największych targowisk w Cieszynie

\begin{tabular}{|c|c|c|}
\hline Wyszczególnienie & $\begin{array}{c}\text { Targowisko } \\
\text { przy ul. Katowickiej }\end{array}$ & $\begin{array}{l}\text { Targowisko } \\
\text { przy al. Łyska }\end{array}$ \\
\hline Data powstania & początek lat 90. XX w. & $1993 \mathrm{r}$. \\
\hline $\begin{array}{l}\text { Powierzchnia targowiska } \\
\text { (ha) }\end{array}$ & 1,7 & 0,5 \\
\hline $\begin{array}{l}\text { Średnia powierzchnia stoiska } \\
\left(\mathrm{m}^{2}\right)\end{array}$ & $5-6$ & 10 \\
\hline Liczba stoisk ogółem & 337 & 142 \\
\hline Liczba użytkowanych stoisk & 231 & 141 \\
\hline $\begin{array}{l}\text { Odległość od granicy } \\
\text { państwowej }(\mathrm{m})\end{array}$ & 2000 & 50 \\
\hline Forma własności & sektor publiczny & sektor prywatny \\
\hline Właściciel & $\begin{array}{l}\text { Urząd Miejski } \\
\text { w Cieszynie }\end{array}$ & $\begin{array}{c}\text { Firma Handlowa } \\
\text { Energo-Tur Sp. z o.o. } \\
\text { w Chrzanowie (od } 2008 \text { r.) }\end{array}$ \\
\hline Administrator & $\begin{array}{l}\text { Miejski Zarząd Dróg } \\
\text { w Cieszynie }\end{array}$ & $\begin{array}{c}\text { Firma Handlowa } \\
\text { Energo-Tur Sp. z o.o. } \\
\text { w Chrzanowie (od } 2008 \text { r.) }\end{array}$ \\
\hline
\end{tabular}

Źródło: oprac. własne na podstawie badań terenowych (lipiec 2014).

Na bazar przy ul. Katowickiej prowadzą trzy wejścia, dwa od ul. Katowickiej oraz jedno od ul. Stawowej (ryc. 2). Rozmieszczenie stoisk na bazarze jest nierównomierne. Duża ich koncentracja występuje w południowej części bazaru, z kolei w części północnej występują nieliczne stoiska oraz parking. Z uwagi na to, że bazar funkcjonuje już prawie 30 lat, wymaga modernizacji, gdyż jego wizualny odbiór jest zdecydowanie negatywny.

Drugi z bazarów to targowisko „Juwenia” przy al. Łyska, które znajduje się w odległości ok. $50 \mathrm{~m}$ od polsko-czeskiego przejścia granicznego na Moście Wolności. Bliskość przejścia granicznego powoduje, że dużą część kupujących stanowią mieszkańcy Republiki Czeskiej, tj. ok. 70\% klientów bazaru według szacunków autorki. Na targowisku przy al. Łyska znajdują się 142 stoiska handlowe, skoncentrowane na stosunkowo niewielkiej powierzchni, bo ok. 0,5 ha. Powstałe w $1993 \mathrm{r}$. targowisko jest własnością prywatną należącą do Firmy Handlowej Energo-Tur Sp. z o.o. w Chrzanowie. Targowisko jest czynne sześć dni w tygodniu, z tym że od poniedziałku do piątku w godz. 7:00-15:00, natomiast w soboty w godz. 7:00-13:00. Na bazar prowadzą dwa wejścia (ryc. 3). Odbiór wizualny targowiska jest pozytywny - stoiska posiadają blaszane zadaszenia, a zdecydowana większość rolety antywłamaniowe. W sąsiedztwie bazaru zlokalizowane są parkingi, obsługujące zmotoryzowanych konsumentów, jak również handlowców pracujących na bazarze. 


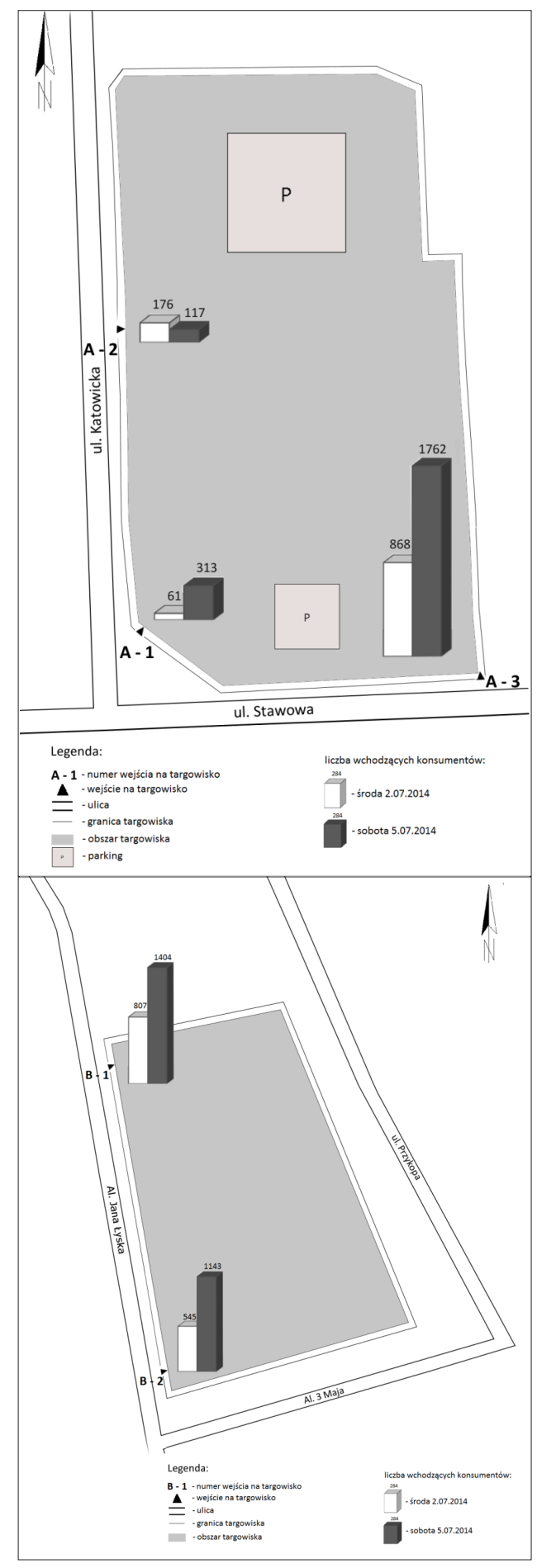

Ryc. 2. Usytuowanie wejść i natężenie ruchu na bazarze przy ul. Katowickiej w Cieszynie (2 i 5 lipca 2014 r.) Źródło: oprac. własne na podstawie badań terenowych (lipiec 2014).

Ryc. 3. Usytuowanie wejść i natężenie ruchu na bazarze przy al. Łyska w Cieszynie (2 i 5 lipca 2014 r.) Źródło: oprac. własne na podstawie badań terenowych (lipiec 2014). 
Charakteryzując oba targowiska warto zwrócić uwagę na jeszcze jeden element, a mianowicie czeskojęzyczną szatę informacyjną, która pojawia się na polskich targowiskach. Są to widoczne w przestrzeni targowiska oznakowania będące nośnikiem informacji, które są ważnym dla funkcjonowania bazarów środkiem porozumiewania się. W związku z tym, że klientami na cieszyńskich bazarach są - jak już wcześniej wspomniano - przede wszystkim przybysze z Republiki Czeskiej (w tym głównie z Czeskiego Cieszyna i okolic), obserwuje się duże nasycenie reklamami czy wywieszkami w języku czeskim, na których widnieją nazwy i ceny towarów w celu usprawnienia wymiany handlowej (fot. 1). Ponadto poruszając się w przestrzeni polskich targowisk uwagę zwraca powszechnie używany język czeski, którym posługują się polscy sprzedawcy (Matykowski, Kulczyńska 2008; Kulczyńska 2015, 2019).

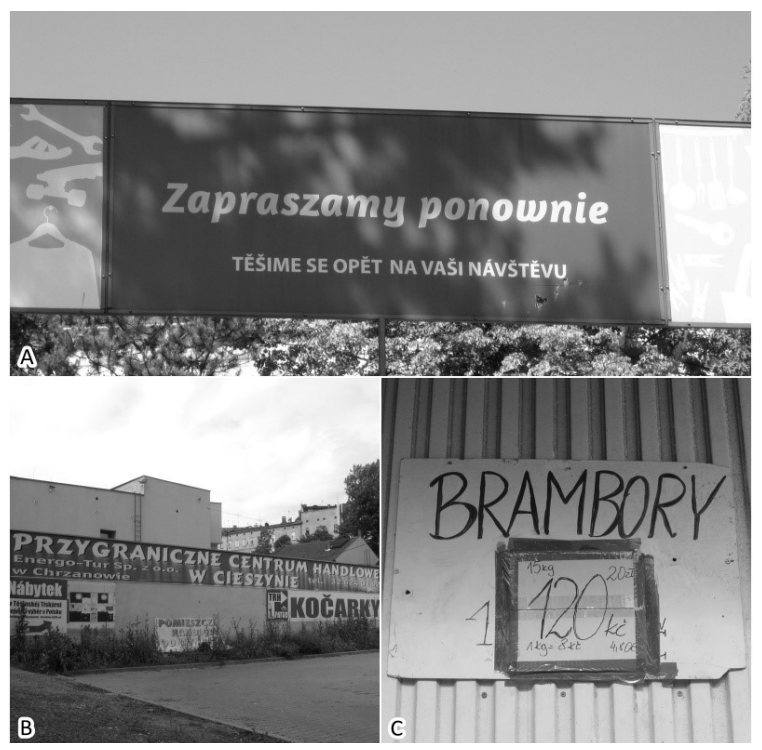

Fot. 1. Czeskojęzyczna szata informacyjna na cieszyńskich bazarach

A - bazar przy ul. Katowickiej, B i C - bazar przy al. Łyska

fot. K. Kulczyńska (2016)

\subsection{Struktura rodzajowa stoisk handlowych na targowiskach przy ul. Katowickiej i al. Łyska w Cieszynie}

Na cieszyńskich bazarach nastąpiła zmiana struktury branżowej stoisk handlowych, choć zawsze dominowała sprzedaż odzieży i obuwia. W tym celu porównano wyniki badań z roku 1999 - okres „boomu targowiskowego”, 2007 roku - „okres niepewności” związany z przystąpieniem Polski i Czech do EU, a później strefy Schengen oraz 2014 roku - „okres stabilizacji”. Prowadzone przez F. Kłosowskiego (2001) badania na bazarze przy ul. Katowickiej w 1999 roku wykazały, że dominowała sprzedaż dwóch artykułów, tj. odzieży $(38,9 \%$ z około 600 czynnych stanowisk) i obuwia (16,6\%). Innymi artykułami chętnie nabywa- 
nymi przez konsumentów były: sprzęt elektroniczny $(8,7 \%)$, galanteria $(8,1 \%)$, sprzęt elektryczny i elektrotechniczny $(5,4 \%)$ czy artykuły muzyczne $(3,2 \%)$. Bardziej rozszerzone badania struktury rodzajowej, obejmującej oba targowiska, przeprowadzili K. Kulczyńska i R. Matykowski (2008). Wyniki tych badań jednoznacznie wskazują, że dominowała sprzedaż odzieży (47,4\% z 359 czynnych stanowisk przy ul. Katowickiej i 41,2\% z 211 czynnych stoisk przy al. Łyska), a także artykułów spożywczych (odpowiednio 6,7\% i 10,0\%) i obuwia (6,4\% i 12,3\%). Ponadto na dużym targowisku pożądanym towarem była bielizna, stąd liczba stoisk oferujących ten towar była znacząca (26 stanowisk - 7,2\%). Natomiast $z$ oferty handlowej zupełnie zniknęły, wskazywane w badaniach F. Kłosowskiego (2001), sprzęt i elektryczny i elektroniczny oraz artykuły muzyczne, a pojawiły się artykuły z wikliny (4,2\% i 2,8\%).

Szczegółowe badania struktury rodzajowej stoisk handlowych na głównych bazarach cieszyńskich przeprowadziła autorka w 2014 roku. Na targowisku miejskim przy ul. Katowickiej użytkowanych było 231 stoisk handlowych, czyli $68,6 \%$ wszystkich stoisk znajdujących się na bazarze. $\mathrm{Z}$ uwagi na to, że targowisko ma charakter przemysłowy występują tylko dwa stoiska oferujące artykuły spożywcze. W grupie stoisk wyspecjalizowanych, czyli takich, które prowadzą wyłącznie sprzedaż jednego asortymentu towaru, najwięcej, bo $39,0 \%$ to stoiska oferujące odzież, w tym damską $18,6 \%$ i męską $16,5 \%$. Ponadto niemało, bo $9,1 \%$ to stoiska prowadzące sprzedaż obuwia, 7,4\% - artykułów bieliźnianych, a $6,1 \%$ - artykułów wyposażenia i wystroju wnętrz (w tym cztery stoiska $\mathrm{z}$ wikliną). Natomiast $\mathrm{w}$ grupie stoisk wielobranżowych dominują stoiska z przewagą odzieży damskiej (9,5\%) i odzieży męskiej $(3,5 \%)$ (tab. 2).

Targowisko „Juwenia” przy al. Łyska wyposażone jest w 141 stoisk, które są użytkowane, co stanowi aż 99,3\% wszystkich stoisk handlowych znajdujących się na bazarze. Spośród użytkowanych stoisk $71,9 \%$ stanowią stoiska wyspecjalizowane, w tym prowadzące głównie sprzedaż odzieży damskiej $(21,3 \%)$ i odzieży męskiej (13,5\%). Generalnie liczba stoisk prowadzących sprzedaż odzieży wynosi 57, co stanowi 40,4\% wszystkich wyspecjalizowanych stoisk na bazarze. Drugim najczęściej sprzedawanym towarem na bazarze są artykuły spożywcze $(11,3 \%)$, a trzecim - obuwie $(9,9 \%)$. Na pojedynczych stoiskach wyspecjalizowanych sprzedaje się galanterię skórzaną $(0,7 \%)$ oraz artykuły wyposażenia i wystroju wnętrz $(0,7 \%)$. Tymczasem stoiska wielobranżowe występują w liczbie 39 (28,1\% ogółu użytkowanych stoisk na bazarze), na których dominuje sprzedaż odzieży $(10,6 \%)$, w tym głównie odzieży damskiej $(9,2 \%)$, a także obuwia $(6,4 \%)$ oraz artykułów bieliźnianych (4,3\%). Pojedyncze stoiska wielobranżowe prowadzą sprzedaż artykułów spożywczych, narzędzi, odzieży dziecięcej i męskiej, artykułów wędkarskich oraz artykułów chemii gospodarczej (płyny do płukania tkanin, proszki do prania itp.). Ponadto na targowisku przy al. Łyska znajdują się dwa kantory, co zapewne wynika z bliskości granicy państwowej (ok. $50 \mathrm{~m}$ ). 
Tabela 2. Struktura rodzajowa stoisk handlowych na cieszyńskich bazarach (2.07.2014)

\begin{tabular}{|c|c|c|c|c|}
\hline \multirow{3}{*}{ Stoisko handlowe } & \multicolumn{2}{|c|}{$\begin{array}{l}\text { Targowisko } \\
\text { przy al. Łyska }\end{array}$} & \multicolumn{2}{|c|}{$\begin{array}{c}\text { Targowisko } \\
\text { przy ul. Katowickie }\end{array}$} \\
\hline & \multicolumn{4}{|c|}{ liczba stoisk handlowych } \\
\hline & ogółem & $\mathrm{w} \%$ & ogółem & $\mathrm{w} \%$ \\
\hline Stoisko zagospodarowane & 139 & 97,2 & 223 & 66,2 \\
\hline w tym wyspecjalizowane: & 100 & 71,9 & 176 & 78,9 \\
\hline 1. Odziė̇ & 57 & 40,4 & 90 & 39,0 \\
\hline 2. Art. spożywcze & 16 & 11,3 & 2 & 0,9 \\
\hline 3. Obuwie & 14 & 9,9 & 21 & 9,1 \\
\hline 4. Art. bieliźniane & 5 & 3,5 & 17 & 7,4 \\
\hline $\begin{array}{l}\text { Art. gospodarstwa } \\
\text { domowego }\end{array}$ & 3 & 2,1 & 5 & 2,2 \\
\hline $\begin{array}{l}\text { Art. wyposażenia/wystroju } \\
\text { wnętrz }\end{array}$ & 3 & 2,1 & 14 & 6,1 \\
\hline 7. Galanteria skórzana & 1 & 0,7 & 4 & 1,7 \\
\hline 8. Torebki i plecaki & 0 & 0,0 & 9 & 3,9 \\
\hline 9. Art. wędkarskie & 0 & 0,0 & 3 & 1,3 \\
\hline 10. Parasole & 0 & 0,0 & 3 & 1,3 \\
\hline 11. Pozostałe & 1 & 0,7 & 5 & 2,2 \\
\hline w tym wielobranżowe $\mathrm{z}$ przewagą: & 39 & 28,1 & 47 & 21,1 \\
\hline 1. Odzieży damskiej & 15 & 10,6 & 34 & 14,7 \\
\hline 2. Obuwia & 9 & 6,4 & 3 & 1,3 \\
\hline 3. Art. bieliźnianych & 6 & 4,3 & 3 & 1,3 \\
\hline 4. Art. gospodarstwa domowego & 3 & 2,1 & 3 & 1,3 \\
\hline 5. $\quad$ Narzędzi & 1 & 0,7 & 3 & 1,3 \\
\hline 6. $\quad$ Pozostałe & 5 & 3,5 & 1 & 0,4 \\
\hline Inne stoiska & 2 & 1,4 & 8 & 2,4 \\
\hline 1. Biuro bazaru & 0 & 0,0 & 1 & 0,4 \\
\hline 2. Kantor & 2 & 1,4 & 0 & 0,0 \\
\hline 3. Magazyn & 0 & 0,0 & 2 & 0,9 \\
\hline 4. Punkt gastronomiczny & 0 & 0,0 & 4 & 1,7 \\
\hline 5. $\mathrm{WC}$ & 0 & 0,0 & 1 & 0,4 \\
\hline Stoisko niezagospodarowane & 1 & 0,7 & 106 & 31,4 \\
\hline Razem & 142 & 100,0 & 337 & 100,0 \\
\hline
\end{tabular}

Źródło: oprac. własne na podstawie badań terenowych (lipiec 2014). 
Na głównych bazarach w Cieszynie zauważa się dużą dysproporcję w liczbie stoisk, która determinowana jest przede wszystkim powierzchnią zajmowaną przez targowiska. Choć to przy ul. Katowickiej jest dużo większe zarówno pod względem powierzchni, jak i liczby stoisk, to jednak zaskakuje liczba stoisk pustych -106 , które stanowią prawie $1 / 3$ wszystkich stoisk na bazarze. Porównując strukturę użytkowania stoisk handlowych w kategoriach: stoiska wyspecjalizowane i wielobranżowe zauważa się, że dominują te pierwsze (76,2\% użytkowanych stoisk na obu bazarach), które w większości oferują odzież oraz obuwie. Odwołując się do tabeli 3 można dostrzec, że proporcje pomiędzy tymi kategoriami stoisk handlowych są podobne na obu analizowanych bazarach, choć bazary różnią się wielkością i położeniem (por. rozdz. 2).

Tabela 3. Wyspecjalizowane i wielobranżowe stoiska handlowe na bazarach w Cieszynie (2.07.2014)

\begin{tabular}{|c|c|c|c|c|c|}
\hline \multirow{3}{*}{ Bazar } & \multicolumn{4}{|c|}{ Liczba stoisk } & \multirow{3}{*}{ Razem } \\
\hline & \multicolumn{2}{|c|}{ wyspecjalizowane } & \multicolumn{2}{|c|}{ wielobranżowe } & \\
\hline & w l. bez. & w \% & w l. bez. & w \% & \\
\hline ul. Katowicka & 176 & 78,9 & 47 & 21,1 & 223 \\
\hline Stoiska spożywcze & 2 & 100,0 & 0 & 0,0 & 2 \\
\hline Stoiska przemysłowe & 174 & 78,7 & 47 & 21,3 & 221 \\
\hline al. Łyska & 100 & 71,9 & 39 & 28,1 & 139 \\
\hline Stoiska spożywcze & 16 & 94,1 & 1 & 5,9 & 17 \\
\hline Stoiska przemysłowe & 84 & 68,9 & 38 & 31,1 & 122 \\
\hline Razem & 276 & 76,2 & 86 & 23,8 & 362 \\
\hline
\end{tabular}

Źródło: oprac. własne na podstawie badań terenowych (lipiec 2014).

Tymczasem analizując strukturę stoisk w rozbiciu na te prowadzące sprzedaż artykułów spożywczych i artykułów przemysłowych zauważa się dość wyraźną różnicę w ich liczbie na obu bazarach. Bazar przy ul. Katowickiej ma charakter przemysłowy, zatem powszechnie występują stoiska o charakterze przemysłowym. Natomiast na bazarze przy al. Łyska 17 stoisk prowadzi sprzedaż artykułów spożywczych, co stanowi 12,2\% wszystkich użytkowanych stoisk.

Na podstawie przeprowadzonej analizy trudno jest dokonać charakterystyki zmian struktury branżowej cieszyńskich targowisk w szerszym kontekście, ponieważ bazując na badaniach różnych autorów napotyka się na barierę w postaci mniej lub bardziej rozbudowanej klasyfikacji stoisk ze względu na sprzedawany asortyment, a także brak informacji na temat sposobu agregacji danych zebranych w drodze inwentaryzacji. Niemniej można stwierdzić, że nastąpiła pewna zmiana struktury branżowej w pierwszej dekadzie XXI wieku. Z oferty handlowej 
zniknęły artykuły elektryczne, elektroniczne i muzyczne, a pojawiły się wyroby z wikliny. W późniejszym okresie nie zaobserwowano większych zmian oferty towarowej cieszyńskich bazarów, poza tym że zaprzestano sprzedaży artykułów drogeryjno-kosmetycznych. Ta przeniosła się do sklepów stacjonarnych.

\subsection{Natężenie ruchu konsumentów na bazarach}

Targowiska przy ul. Katowickiej i al. Łyska znajdują się w głównej strefie przemieszczeń konsumentów pochodzących z Czech (wcześniej również ze Słowacji) (Panic 2010). Stanowią oni zasadniczą część kupujących na obu bazarach, zarówno obecnie, jak i na początku lat 90. XX wieku, kiedy targowiska dopiero powstawały (Konecka, Weltrowska 1997; Kłosowski, Runge 1999, 2002; Kłosowski 2001).

Pomiary natężenia ruchu na cieszyńskich bazarach prowadzono już w latach 90. ubiegłego wieku. Badania B. Koneckiej i J. Weltrowskiej (1997: 224) wykazały, że bazar przy ul. Katowickiej w dniu 10 września 1994 roku (sobota) w godzinach $8.00-12.00$ odwiedziło 22,3 tys. osób, a najwięcej między godziną 9:00 a 10:00 - 7,3 tys. osób, co stanowiło ponad 1/3 wszystkich odwiedzających. Natomiast na tzw. małym targowisku przy ul. 3 Maja, wykorzystującym zabudowania amfiteatru (dziś już nie istnieje, ale w sąsiedztwie powstał bazar przy al. Łyska), natężenie ruchu wynosiło 4,4 tys. osób, czyli łącznie oba targowiska odwiedziło ponad 26 tys. osób. Przyczyną tak dużego natężenia ruchu na bazarach był przede wszystkim niedobór infrastruktury handlowej oraz brak możliwości zaspokojenia popytu przez podaż wewnętrzną. Wraz ze zmianami politycznymi i gospodarczymi zapoczątkowanymi na przełomie lat 80 . i 90 . ubiegłego wieku najszybciej obserwowalną zmianą było powstawanie handlu detalicznego. Najłatwiej było zorganizować handel na bazarach, bo nie wymagało to dużych nakładów finansowych (np. wystarczyło łóżko polowe, na którym rozkładało się towar do sprzedaży). Okres ten charakteryzował się ogromnym popytem (preferowanie ilości nad jakością). Kupowano każdy dostępny towar nie zwracając uwagi na jego jakość. Ten boom targowiskowy trwał mniej więcej do końca lat 90.

Pod koniec lat 90. zaobserwowano zasadniczy spadek natężenia ruchu na targowisku przy ul. Katowickiej. W 1999 roku liczba potencjalnych klientów kształtowała się na poziomie 8-12 tys. osób (Kłosowski 2001). Pierwszą dekadę XXI wieku cechuje dalszy spadek natężenia ruchu konsumentów na cieszyńskich bazarach. W tym miejscu należy powołać się na badania K. Kulczyńskiej i R. Matykowskiego (2008). Dotyczą one tylko dwóch godzin funkcjonowania bazarów, kiedy to przypada szczyt zakupów (8:00-10:00, środa 20.06.2007), niemniej można je porównać z badaniami wykonanymi w 2014 roku. Targowisko przy al. Łyska odwiedziło w tym czasie 440 osób, a przy ul. Katowickiej -874 osoby. 
Podobne badania natężenia ruchu przeprowadzono 2 lipca 2014 roku (środa). Targowisko przy ul. Katowickiej w godzinach 7:00-13:00 odwiedziło 1105 osób, najwięcej między godziną 9:00-10:00 (338 osób). Powtórzone badania w dniu 5 lipca 2014 roku (sobota) pokazały natomiast, że najwięcej konsumentów odwiedziło bazar w godzinach 8:00-9:00 (628 osób), a ogółem na bazar weszły 2192 osoby, czyli o 98,4\% więcej aniżeli w środę (ryc. 2 i 4). Przypuszczać można, że głównym czynnikiem kształtującym ruch na bazarach była pogoda - w sobotę świeciło słońce, natomiast w środę padał deszcz. Ponadto innym czynnikiem mającym wpływ na zwiększony ruch na bazarach w sobotę jest fakt, że dla większości konsumentów jest to dzień wolny od pracy.

W tym samym czasie badania natężenia ruchu konsumentów przeprowadzono na targowisku przy al. Łyska. Wykazały one, że zarówno w środę, jak i sobotę najwięcej osób weszło na bazar w godzinach 9:00-10:00, z tym że w sobotę było to o 45,5\% osób więcej aniżeli w środę (393 osoby). Ogółem na bazar w środę weszły 1352 osoby, natomiast w sobotę prawie dwukrotnie więcej, bo 2547 osób (ryc. 3 i 4). Porównując badania z lat 2007 i 2014 zaobserwować można wzrost klientów na bazarze przy al. Łyska o 200 osób, ale spadek przy ul. Katowickiej o 245 osób. Być może jest to zbyt daleko wysunięty wniosek, ponieważ dotyczy tylko jednego dnia tygodnia (środy) i dwóch godzin funkcjonowania bazarów. Niemniej może stanowić przyczynek do podjęcia dalszych badań.

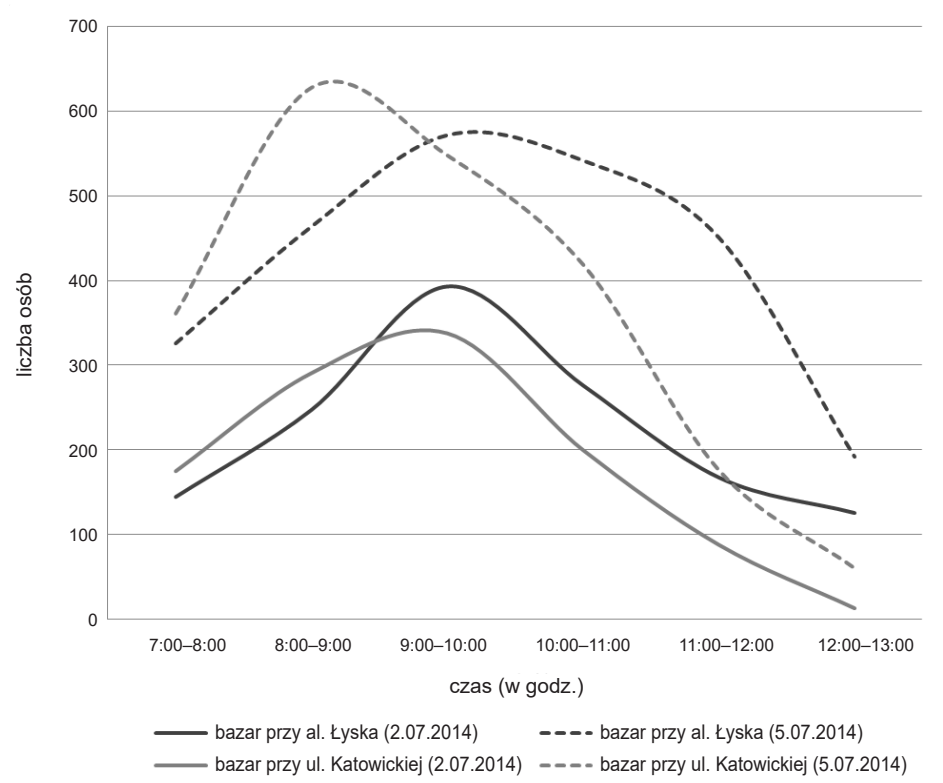

Ryc. 4. Natężenie ruchu na bazarach w Cieszynie w środę (2 lipca 2014 r.) i sobotę (5 lipca 2014 r.)

Źródło: oprac. własne na podstawie badań terenowych (lipiec 2014). 
Na podstawie pomiaru natężenia ruchu można stwierdzić, że zainteresowanie konsumentów targowiskami maleje. W 2014 roku kształtowało się ono na poziomie zaledwie 2,5 tys. osób w środę oraz 5,8 tys. osób w sobotę. Dzisiaj więcej klientów odwiedza targowisko przy al. Łyska (3899 osób), bo aż o 48,6\% aniżeli targowisko przy ul. Katowickiej. Fakt ten można wythumaczyć bliskim położeniem targowiska w stosunku do granicy państwowej (do przejścia granicznego na Moście Wolności - 50 m, do przejścia granicznego na Moście Przyjaźni - 100 m), a także zadbaną infrastrukturą, która zarówno zachęca do pracy na bazarze, jak i realizacji zakupów.

\subsection{Bazary w ocenie mieszkańców Cieszyna}

Spośród 119 respondentów większość stanowiły kobiety, bo aż 64\% ogółu badanych, a tylko 36\% mężczyźni. Wśród badanych konsumentów najwięcej było osób mających 60 lat i więcej (26\%). Kolejne pod względem liczebności grupy wiekowe stanowily osoby w wieku 50-59 lat (21\%) oraz 40-49 lat (20\%). Wynika stąd, że $67 \%$ badanych to osoby w wieku średnim i starszym. Ankietę przeprowadzono wśród mieszkańców Cieszyna, którzy nie tylko są klientami bazarów, ale również użytkownikami przestrzeni miejskiej, w której zlokalizowane są bazary.

W pierwszej kolejności poproszono respondentów o wyrażenie opinii na temat obecności bazarów w przestrzeni miejskiej Cieszyna. Badania wykazały, że 66\% ankietowanych zadeklarowało pozytywny stosunek do istnienia bazarów w Cieszynie, zaledwie $8 \%$ uznało, że bazary cieszyńskie są negatywnym zjawiskiem, a $25 \%$ nie miało zdania na ten temat. Respondenci, którzy pozytywnie odbierają funkcjonowanie bazarów w przestrzeni miasta (79 ankietowanych - 100\%), najczęściej jako argumenty wskazywali niższe ceny towarów (23\% wskazań), „klimat miejsca" (20\%), szeroki wybór produktów (18\%), wysoką jakość produktów (12\%) czy też korzystną lokalizację bazaru (10\%) (ryc. 5).

Respondenci mający negatywny stosunek do cieszyńskich bazarów (10 ankietowanych), jako przyczynę wskazywali brak organizacji targowiska (4 osoby), wąski wybór produktów (3), nadmierny hałas (1), niekorzystną lokalizację bazaru (1), a także obecność obcokrajowców na targowisku (1). Analizując wypowiedzi respondentów warto zwrócić uwagę, że spośród szerokiej gamy czynników przemawiających za korzystaniem z bazaru czy też nie są trzy, które wskazano raz jako pozytywne, a raz jako negatywne, tj. lokalizacja bazaru, jakość produktów oraz obecność obcokrajowców.

W dalszej części badania ankietowani dokonali oceny problemów, jakie pojawiają się w dni targowe w pobliżu cieszyńskich bazarów. Badanie ukazuje, że jedynym problemem jest brak miejsc parkingowych, na co wskazało $68 \%$ ankietowanych. Dla $43 \%$ respondentów problem stanowi nadmierny hałas zarówno w godzinach funkcjonowania bazarów, jak i w godzinach wczesnoporannych, kiedy to handlowcy przygotowują swoje stoiska do sprzedaży. Niemniej, $44 \%$ respondentów takiego problemu nie dostrzega (ryc. 6). 


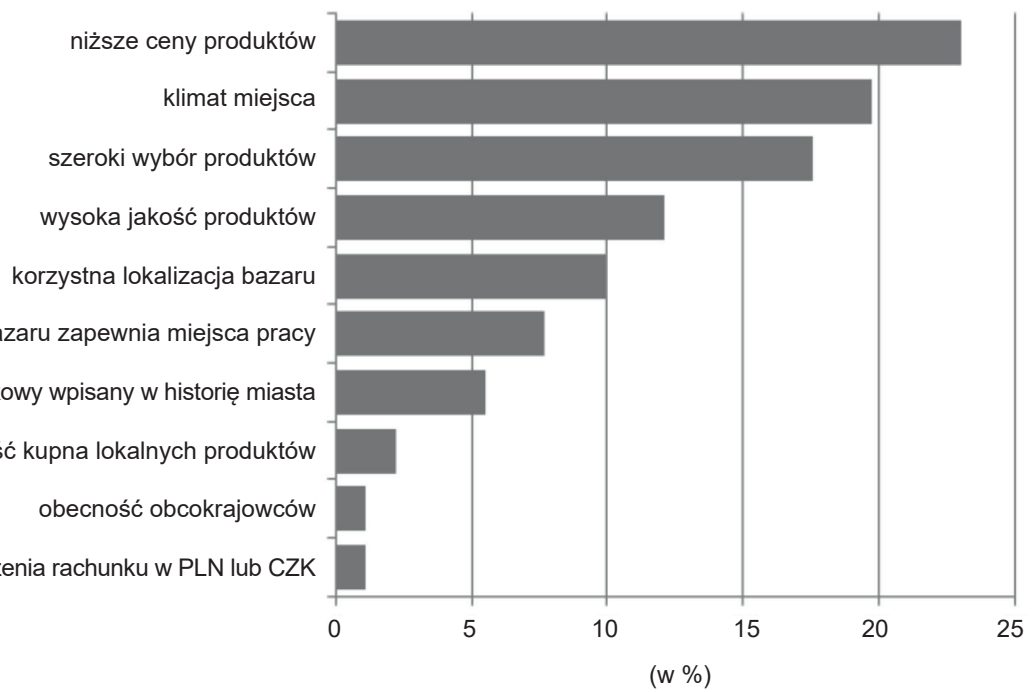

Ryc. 5. Argumenty przemawiające za obecnością bazarów w przestrzeni miejskiej Cieszyna $(\mathrm{n}=79)$

Źródło: oprac. własne na podstawie badań terenowych (lipiec 2014).

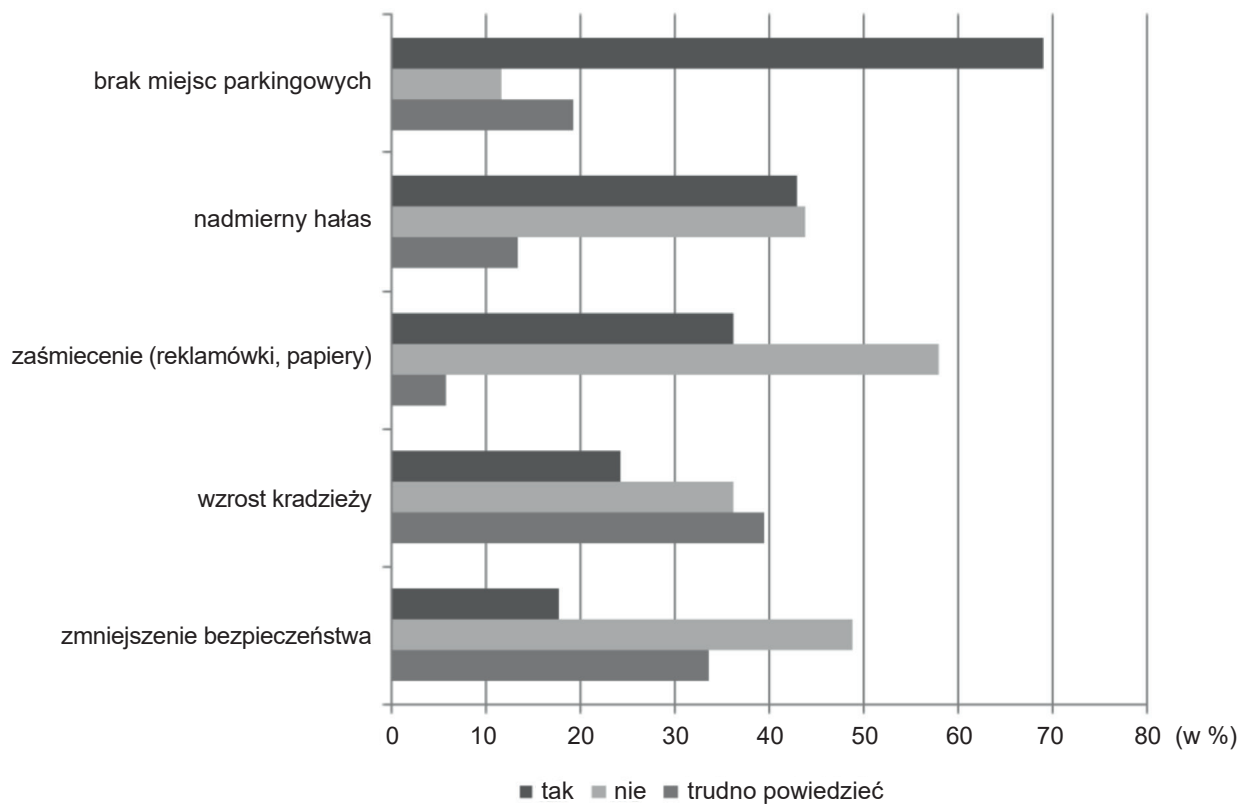

Ryc. 6. Zidentyfikowane problemy w okolicy cieszyńskich bazarów i ich ocena $(n=119)$ Źródło: oprac. własne na podstawie badań ankietowych (lipiec 2014). 
Ankietowani wyrazili również swoją opinię na temat dostępności czasowej targowisk w Cieszynie. Badania wykazały, że mieszkańcy Cieszyna mają bardzo podzielone zdania, bowiem 50\% ankietowanych uważa, że targowiska w Cieszynie powinny być czynne codziennie, z czym nie zgadza się $49 \%$ ankietowanych uznając, że nie ma takiej potrzeby. Tylko $1 \%$ badanych nie miało zdania na ten temat.

Zarówno w prasie, jak i literaturze naukowej już od dłuższego czasu pisze się o kurczeniu się handlu bazarowego, szczególnie tego zlokalizowanego przy wewnętrznych granicach Unii Europejskiej, a jako czynnik tych zmian często wskazuje się wyrównywanie cen po obu stronach granicy (Kulczyńska 2008). Stąd też zapytano respondentów czy są za utrzymaniem, czy też likwidacją bazarów. Z grupy 119 respondentów 91\% osób chce utrzymania bazarów, z czego $73 \%$ w obecnej formie. Zmniejszenia liczby stoisk na bazarach zadeklarowało $8 \%$ badanych, a zwiększenia 4\%. Niektórzy respondenci opowiedzieli się za połączeniem targowisk (7\%), inni zaś za ich likwidacją (8\%) (ryc. 7).

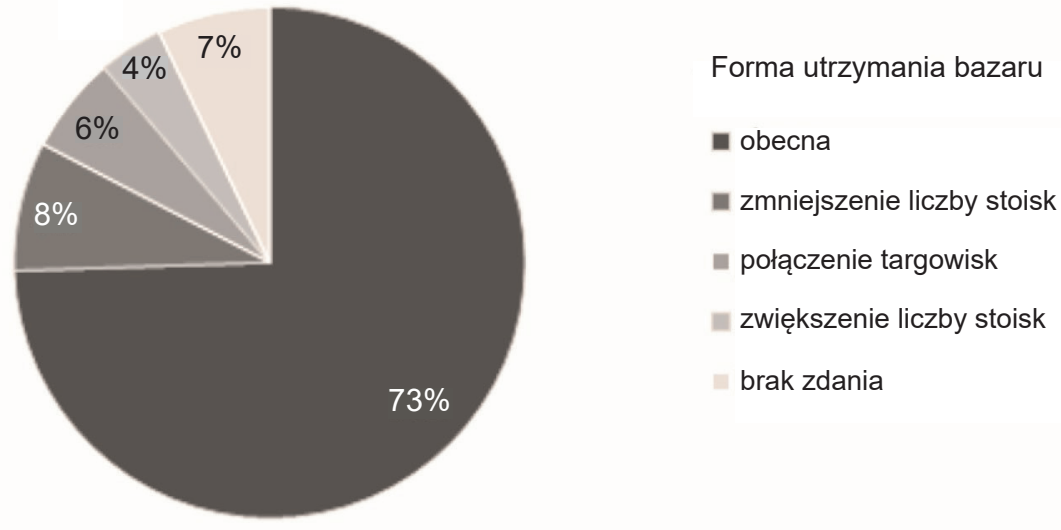

Ryc. 7. Opinia mieszkańców na temat form utrzymania bazarów w Cieszynie $(\mathrm{n}=108)$ Źródło: oprac. własne na podstawie badań ankietowych (lipiec 2014).

Badania wskazują, że mieszkańcy Cieszyna mimo słabnącej roli bazarów, nadal robią tam zakupy. Aż $85 \%$ ankietowanych deklaruje, że robi zakupy na cieszyńskich bazarach. Nabywanie towarów na bazarze motywują głównie konkurencyjnymi cenami (35\% wskazań), wysoką jakością produktów (19\%), jak również szerokim wyborem produktów (15\%). Na bazarach ankietowani kupują zarówno artykuły spożywcze (62\%), jak i artykuły przemysłowe (38\%). Wśród artykułów spożywczych najczęściej kupowane są warzywa (29\%) i owoce (24\%), co zapewne związane jest z porą roku przeprowadzania niniejszej ankiety - lipiec, kiedy to dostępność tych produktów jest największa, a ich jakość jest najwyższa. 


\subsection{Podsumowanie}

Celem artykułu było przedstawienie tendencji zmian przygranicznego handlu targowiskowego w Cieszynie. Bazując na danych pierwotnych zebranych w drodze badań terenowych oraz materiałach wtórnych pobranych ze strony internetowej GUS, uzyskano odpowiedzi na postawione we wstępie pytania badawcze, skłaniające do następujących stwierdzeń i wniosków:

1. W latach 1995-2018 nastąpił spadek liczby targowisk (z 9 do 6), któremu towarzyszył spadek wielkości powierzchni targowisk o $1 / 3$ i liczby stoisk handlowych o $2 / 3$. Najbardziej widoczne zmiany zaszły na targowisku przy ul. Katowickiej, które w latach 90. było głównym miejscem dokonywania zakupów, również przez klientów czeskich. Znacząco zmniejszyła się tam liczba użytkowanych stoisk. Wpływ na taki stan rzeczy miało kilka czynników, a mianowicie: (a) znaczne oddalenie targowiska od granicy, (b) zbyt wysokie opłaty za użytkowanie stoiska handlowego, (c) pojawienie się w sąsiedztwie bazaru sklepu „Kaufland” (o dominującym profilu sprzedaży artykułów spożywczych), (d) pogarszająca się jakość towarów oferowanych na bazarze, (e) coraz bardziej wymagający konsumenci, którzy częściej szukają produktów lepszej jakości, a także (f) likwidacja części stoisk w złym stanie technicznym. Obecnie większym potencjałem cechuje się położone w sąsiedztwie granicy państwowej targowisko przy al. Łyska.

2. Kurczeniu się liczby stanowisk na bazarach, a także liczby samych targowisk, towarzyszyła poniekąd zmiana struktury branżowej. Polegała ona na zaniku stanowisk oferujących sprzęt elektroniczny, elektryczny, elektrotechniczny i artykuły drogeryjno-kosmetyczne, których sprzedaż przeniosła się do stacjonarnych, wyspecjalizowanych placówek handlowych. W to miejsce pojawiły się natomiast stoiska sprzedające wyroby $\mathrm{z}$ wikliny, chętnie kupowane przez klientów z Czech. Mimo zaistniałych zmian, zawsze dominowała sprzedaż odzieży i obuwia, a udział stanowisk oferujących te artykuły w badanym okresie zwiększył się.

3. Wyraźnie zmalało natężenie ruchu na bazarach. W latach 90. Cieszyn w każdą środę i sobotę przekształcał się w wielki ośrodek handlowy, do którego zmierzali z jednej strony sprzedawcy z różnych stron Polski, z drugiej zaś kupujący, w tym także z Czech i Słowacji (Panic 2010). Początek XXI wieku przyniósł znaczący spadek liczby konsumentów na bazarach, pomimo zniesienia obostrzeń w ruchu granicznym (liberalizacja przepisów celnych i zniesienie kontroli paszportowej). Analizując natężenie ruchu w układzie dwóch największych targowisk w mieście stwierdza się, że obecnie większy ruch obserwuje się na bazarze przy al. Łyska, szczególnie w soboty.

4. Przeprowadzone badania opinii mieszkańców na temat przygranicznych bazarów wykazały, że większość ankietowanych chętnie robi tam zakupy, 
przede wszystkim dlatego, że ceny produktów są tam niższe niż w sklepach, a także z uwagi na niepowtarzalny klimat tego miejsca. Głównym problemem z funkcjonowaniem bazarów - jak wskazują wyniki badań - jest brak miejsc postojowych dla zmotoryzowanych konsumentów w dni targowe. Mimo to respondenci są za ich utrzymaniem i to w obecnej formie.

Cieszyńskie targowiska od końca lat 90. XX wieku ulegają stopniowemu kurczeniu się zarówno pod względem liczby konsumentów, jak i liczby stanowisk handlowych. Pomimo tego nadal stanowią jedną z ważniejszych form działalności handlowych prowadzonych w Cieszynie. Bazary są jednym z wielu miejsc, które Czesi - a przede wszystkim mieszkańcy Czeskiego Cieszyna - wybierają na realizację zakupów.

Przygraniczny handel bazarowy to część historii miasta. Funkcjonują bowiem prawie 30 lat. Po okresie boomu lat 90 . nastąpił czas niepewności związany z przystąpieniem do UE oraz strefy Schengen, co - jak się później okazało - nie miało znaczącego wpływu na funkcjonowanie handlu bazarowego. Przyczyną ich kurczenia się było otwieranie kolejnych supermarketów i dyskontów, które częściowo przejęły klientów z bazarów. To zaś uruchomiło proces zamykania niektórych bazarów, a w przypadku tych, które pozostały - likwidacji części stoisk handlowych. Handel targowiskowy w Cieszynie poprzez dostosowanie się do zaistniałych warunków, osiągnął pewien stopień stabilizacji, choć trudno jest dzisiaj wyrokować czy największy bazar ostatniej dekady XX wieku (przy ul. Katowickiej) przetrwa próbę czasu i doczeka się modernizacji, czy też przeciwnie - działalność handlowa zostanie na nim zaniechana. Odpowiedzi na te i inne pytania powinny dostarczyć badania, które autorka podejmie w najbliższej przyszłości.

\section{Literatura}

Dołzbłasz S., 2013, Cross-border co-operation in the euroregions at the Polish-Czech and Polish-Slovak borders, „European Countryside”, 5(2): 102-114.

Dołzbłasz S., 2015, Cieszyn-Czeski Cieszyn - wybrane aspekty funkcjonowania miasta podzielonego na granicy polsko-czeskiej w kontekście transgranicznej mobilności mieszkańców, „Studia z Geografii Politycznej i Historycznej”, 4: 201-219.

Hamulczuk M., 2016, Czynniki warunkujace kierunki zmian handlu targowiskowego w Polsce, ,Roczniki Naukowe Ekonomii Rolnictwa i Rozwoju Obszarów Wiejskich”, 103(2): 69-77.

Klima E., Zajączkowski J., 2008, Marketplace retail in Poland in the years 1995-2006, „Space-Society-Economy”, 8: 143-154.

Kłosowski F., 2001, Usługi w miastach granicznych Cieszyn i Czeski Cieszyn, [w:] Runge J. (red.), Problemy społeczno-gospodarcze pogranicza polsko-czeskiego na przykładzie Śląska Cieszyńskiego, Wydawnictwo Uniwersytetu Śląskiego, Katowice: 189-213. 
Kłosowski F., Runge J., 1999, Ustugi w przestrzeni miejskiej na przykładzie Cieszyna, [w:] Przestrzeń miejska. Jej organizacja i przemiany, XII Konwersatorium Wiedzy o Mieście: 21-29, Łódź.

Kłosowski F., Runge J., 2002, Usługi w mieście przygranicznym na przykładzie Cieszyna, „Geographia. Studia et Dissertationes”, 25: 73-89, Katowice.

Konecka B., Weltrowska J., 1997, Funkcje handlowe Cieszyna i Cieszyna Czeskiego, [w:] Maik M., Sokołowski D. (red.), Geografia osadnictwa, ludności i turyzmu wobec transformacji systemowej, Wydawnictwo Uniwersytetu Mikołaja Kopernika, Toruń: 223-226.

Kowalczyk A., Nawrocki T., 1999, Wspótpraca transgraniczna $w$ „,miastach podzielonych” - na przykładzie miast Stubice-Frankfurt nad Odrą oraz Cieszyn-Český Těšín, [w:] Mync A., Szul R. (red.), Rola granicy i współpracy transgranicznej w rozwoju regionalnym i lokalnym, Wydawnictwo Europejskiego Instytutu Rozwoju Regionalnego i Lokalnego, Warszawa: 188-202.

Kropiwnicki J., 2003, Fenomen bazarów, „Acta Universitatis Lodziensis. Folia Oeconomica", 170: 107-120.

Kulczyńska K., 2008, Rozmieszczenie i funkcjonowanie ustug w mieście przygranicznym Stubice, [w:] Słodczyk J., Szafranek E. (red.), Mechanizmy i uwarunkowania budowania konkurencyjności miast, Wydawnictwo Uniwersytetu Opolskiego, Opole: 203-212.

Kulczyńska K., 2015, Models of service systems in the split towns of the Polish-German and Polish-Czech borderlands, „Annales Universitatis Paedagogicae Cracoviensis. Studia Geographica", 8(178): 107-122.

Kulczyńska K., 2019, Zachowania konsumentów w miastach podzielonych polsko-niemieckiego i polsko-czeskiego obszaru przygranicznego, Wydawnictwo Naukowe Uniwersytetu im. Adama Mickiewicza w Poznaniu, Poznań.

Kulczyńska K., Matykowski R., 2008, Struktura przestrzenno-handlowa przygranicznego zespołu miejskiego Česky Těšin-Cieszyn, [w:] Świątek D., Bednarek M., Siłka P. (red.), Współczesne problemy badawcze geografii polskiej - geografia człowieka, „Dokumentacja Geograficzna”, 36: 202-207.

Kulczyńska K., Matykowski R., Siwek T., 2009, Cieszyn i Śląsk Cieszyński a przemiany polityczne na pograniczu Olzy w XX wieku, [w:] Kulesza M. (red.), Geografia historyczna jako determinanta rozwoju nauk humanistycznych, Państwowa Wyższa Szkoła Zawodowa im. Witelona, Legnica-Lódź: 97-107.

Malinowska M., 2016, Targowiska w Polsce - schyłek czy rozkwit?, „Studia Ekonomiczne. Zeszyty Naukowe Uniwersytetu Ekonomicznego w Katowicach”, 302: 109-122.

Matykowski R., Kulczyńska K., 2008, Społeczno-kulturowe i przestrzenne aspekty szaty informacyjnej miasta przygranicznego, [w:] Orłowska E. (red.), Kulturowy aspekt badań geograficznych. Studia teoretyczne i regionalne, Polskie Towarzystwo Geograficzne - Oddział Wrocławski, Wrocław, 1: 141-157.

Matykowski R., Schaefer K., 1996, Spoleczne i ekonomiczne aspekty funkcjonowania przygranicznego zespotu miejskiego Gubin-Guben, „Biuletyn KPZK PAN”, 171: 91-103.

Metodologia badań rynku targowiskowego. Przewodnik do badań na targowiskach. Materiat przygotowany do celów szkoleniowych, Ministerstwo Rolnictwa i Rozwoju Wsi, Departament Przetwórstwa i Rynków Rolnych, październik 2002, Warszawa. 
Miecik I.T., 2016, Cieszyn odzyskany, „Gazeta Wyborcza”, 30 (6.02.2016).

Nitschke B., 2010, Handel przygraniczny jako egzemplifikacja form aktywizacji społeczno-gospodarczej $w$ gminach przygranicznych $w$ świetle polskiej prasy, [w:] Jańczak J., Musiał-Karg M., Wojnicz L. (red.), Pogranicze polsko-niemieckie na tle granic i pograniczy europejskich, Wydawnictwo Naukowe Wydziału Nauk Politycznych i Dziennikarstwa, Uniwersytet im. Adama Mickiewicza w Poznaniu, Poznań: 37-47.

Panic I., 2010, Sytuacja gospodarcza miasta, [w:] Panic I. (red.), Dzieje Cieszyna od pradziejów do czasów współczesnych, Wydawnictwo AVALON T. Janowski sp.j., Cieszyn, 3: 593-606.

Powęska H., 2002, Przestrzenny wymiar handlu transgranicznego w Polsce $w$ ostatniej dekadzie XX wieku, „Geopolitical Studies”, 9.

Powęska H., 2003, Handel transgraniczny: fenomen okresu transformacji i otwierania przestrzeni wymiany międzynarodowej $w$ Polsce $i w$ Europie Środkowej, „Europa XXI wieku", 9: 49-59.

Powęska H., 2007, Zmiany natężenia handlu targowiskowego w Polsce w latach 1999_ 2004, „Oeconomia”, 6(1): 61-70.

Powęska H., 2016, Handel przygraniczny $w$ warunkach zmian przenikalności granicy, Wydawnictwo SGGW, Warszawa.

Rynek Wewnętrzny w 2014 r. Informacje i opracowania statystyczne, 2015, Główny Urząd Statystyczny, Warszawa.

Sojkin B., Michalak Sz., 2018, Targowisko jako miejsce zakupów mieszkańców dużych miast w Polsce, „Handel Wewnętrzny”, 4(375): 327-339.

Werwicki A., 2001, Handel targowiskowy aglomeracji łódzkiej na tle jego znaczenia ogólnopolskiego w latach 1994-1997, „Szlakami Nauki”, 31.

Wojdacki K.P., 2011, Przestrzenne aspekty rozwoju handlu targowiskowego w Polsce, „Handel Wewnętrzny”, 6: 23-35.

Wojdacki K.P., 2016, Terytorialne zróżnicowanie rozwoju handlu targowiskowego w Polsce - analiza statystyczna, „Problemy Zarządzania”, 14, 1(57): 212-231.

Zuba M., Zuba J., 2018, Wpływ położenia podregionów na zmianę liczby stałych targowisk w okresie kryzysu finansowego na przykładzie dwóch przygranicznych województw Polski, ,Roczniki Naukowe Stowarzyszenia Ekonomistów Rolnictwa i Agrobiznesu”, 15(6): 327-332.

Zuzańska-Żyśko E., 2010, Targowisko miejskie w Będzinie. Historia $i$ współczesność, „Prace Wydziału Nauk o Ziemi Uniwersytetu Śląskiego”, 67, Sosnowiec.

Zuzańska-Żyśko E., Sitek S., 2011, Rola handlu targowiskowego w rozwoju miast, [w:] Soja M., Zborowski A. (red.), Człowiek w przestrzeni zurbanizowanej, Instytut Geografii i Gospodarki Przestrzennej, Uniwersytet Jagielloński, Kraków: 271-281.

\section{Źródło internetowe}

https://bip.um.cieszyn.pl/artykuly/1458/miejsce-handlowe-na-terenie-targowisk

Historia artykutu

Data wpływu: 20 marca 2020

Data akceptacji: 3 czerwca 2020 